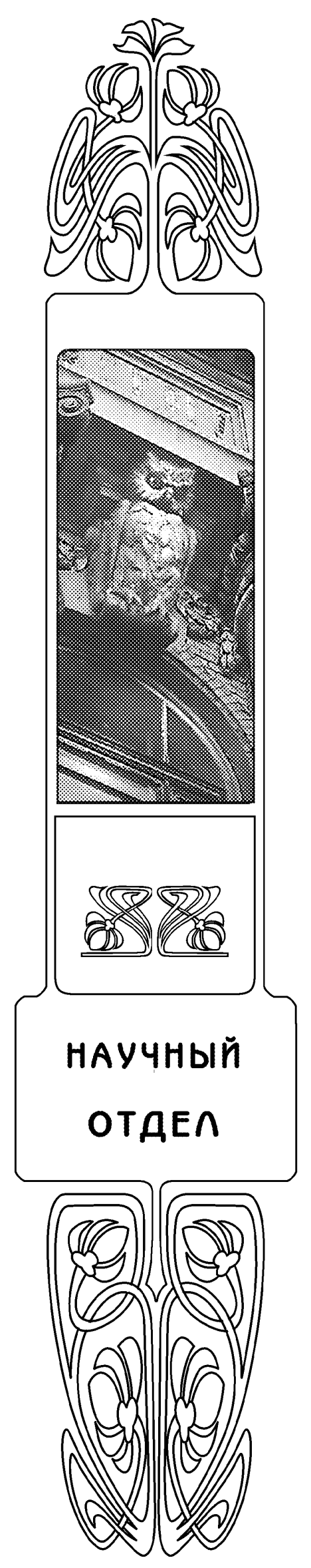

ГЕОЛОГИЯ

УДК 553.98.061.3:551.583.7

\title{
О ПАЛЕОКЛИМАТИЧЕСКОМ КОНТРОЛЕ ПРЕИМУЩЕСТВЕННОГО НЕФТЕ- И ГАЗООБРАЗОВАНИЯ В СВЯЗИ С ОЦЕНКОЙ ПЕРСПЕКТИВ НЕФТЕГАЗОНОСНОСТИ ШЕЛЬФА АРКТИЧЕСКИХ МОРЕЙ РОССИИ
}

\author{
Л.А. Назаркин \\ Научно-исследовательский институт естественных наук \\ Саратовского государственного университета, отделение геологии \\ E-mail: decanat@geol.sgu.ru
}

Установлена прямая зависимость масштабов накопления нефтематеринского органического вещества от среднегодовой температуры, освещенности и пополнения биогенными элементами фотического слоя водной толщи седиментационного бассейна. При прочих благоприятных условиях нефтегенерационный потенциал осадочно-породных бассейнов зависит от их палеоширотного расположения в период накопления нефтематеринских отложений.

Дан прогноз нефте- и газоносности шельфовых зон остальных окраинных арктических морей России.

To Paleoclimatic Control in Oil and Gas Generation as Related to Estimation of Oil and Gas Content Prospects in the Shelves of Russian Arctic Seas

\section{L.A. Nazarkin}

A direct dependence is established between the scale of accumulation of oil source organic matter and the average annual temperature, illumination and supply of biogenic elements to the photic layer of the water mass in a sedimentation basin. Other conditions being favourable, the oil-generating potentials of sedimentary-rock basins depend upon their paleolatitudinal position during accumulation of oil-source deposits.

Oil and gas contents are predicted for the shelf zones of other marginal Arctic seas in Russia.

\section{Введение}

Исходя из фундаментального положения теории образования нефти, выделяющего гидробионты в качестве главного источника нефтематеринского органического вещества (OB), автором [1-5] были проведены исследования влияния биономических условий в фотическом слое воды (температуры, состава и количества биогенных элементов, освещенности) на биологическую продуктивность водоемов, при прочих равных условиях контролирующую динамику накопления ОВ в осадках. В.А.Рябченко [6] установлено, что температура фотического слоя воды проявляет себя в качестве множителя в формуле расчета первичной продукции акваторий.

Автор данной статьи пришел к выводу, что при благоприятном сочетании других факторов нефтеобразования родиной «большой» нефти являются осадочно-породные бассейны (ОПБ), располагавшиеся в период накопления потенциально нефтематеринских толщ в зонах теплого климата. Теплый климат в период осадконакопления мы рассматриваем в качестве необходимого фона, на котором, при благоприятном сочетании всех составляющих процесса образования, аккумуляции и сохранения нефти, происходит формирование ее промышленных скоплений. Анализ палеоширотной локализации нефтематеринских отложений и выявленных скоплений генерированной 
ими нефти позволил прийти к выводу, что более $80 \%$ фанерозойской нефти образовано нефтематеринскими отложениями, накапливавшимися в палеоширотном диапазоне 0-30 [7]. Из них 60\% разведанных запасов обнаружено в приэкваториальных палеоширотах $\left(0-10^{\circ}\right)$.

\section{О раздельном прогнозировании преимущественной нефте- и газоносности недр}

Имея в виду высокий газогенерационный потенциал угленосных и субугленосных отложений и перемещение в посткарбоновое время угленакопления в бореальные зоны [8-10], в 1955 г. автор данной статьи впервые предложил раздельное прогнозирование преимущественной нефте- и газоносности ОПБ в пределах крупных регионов [1]. Зоны холодного климата (высокие палеошироты) прогнозируются преимущественно газоносными, тогда как зоны теплого климата низких палеоширот - преимущественно нефтеносными. Глобальная поляризация преимущественной нефте- и газоносности в постпозднекарбоновое время находит подтверждение при палеоширотном анализе локализации нефтяных и газовых скоплений [4]. В низких палеоширотах возможно образование и крупных скоплений газа, генерированного как при катагенезе терригенного OB, накопившегося в отложениях гумидных зон, так и за счет метаморфизма нефти в жестких термобарических условиях.

После открытия крупных скоплений газа, генетически связанных с угленосными и субугленосными отложениями, возросший интерес к новому, и, как оказалось, главному источнику газообразных углеводородов (УВ) отражен во многих публикациях [11-13]. Проблеме раздельного формирования зон нефте- и газонакопления в зависимости от генетического типа ОВ и степени его метаморфизма посвящено два выпуска трудов ЗапСибНИГНИ $[14,15]$. Эту проблему затрагивает большая часть материалов, опубликованных в сборниках $[16,17]$.

И.П.Жабрев с соавторами [18, с. 12] пришли к выводу, что 65\% выявленных мировых запасов газа генетически связаны с угленосными и субугленосными формациями, при этом главную роль в генерации газа играют угленосные толщи мезозойских отложений, составляющие $80 \%$ объема мезозойского осадочного чехла. Вместе с тем они обращают внимание [14], что к генерации сухого УВ газа могут быть причастны фаерозойские терригенные и карбонатные породы с ОВ аквагенной природы, когда они погружаются в глубинные зоны проявления жесткого катагенеза.

Исследования сотрудников ЗапСибНИГНИ свидетельствуют о том, что на севере Западной Сибири в тюменской свите $\left(J_{1}-J_{2}\right)$ и усть-тазовской серии $\left(K_{1} \mathrm{v}-K_{2} c\right)$ содержится соответственно 18,0 и 15,5 трлн т концентрированного (пласты и линзы угля и углистые породы) и рассеян- ного угольного вещества. Согласно подсчетам М.В.Голицына и соавторов [13], угольное ОВ Западной Сибири могло генерировать 650 трлн м ${ }^{3}$ метана. При этом установлено [19], что на Ямале и Гыданском полуострове проявляется прямая зависимость объемов газовых скоплений от суммарной толщины пластов углей, вмещающих и подстилающих газовые скопления.

\section{Апробация главного вывода автора}

Основные положения проведенного исследования мы отразили в докладе «О перспективах нефтеносности севера Сибири», который 4 августа 1958 г. был заслушан на заседании экспертной комиссии секции нефти и газа экспертно-геологического совета Главгеологии РСФСР. Исходя из палеогеографической обстановки на севере Сибири в пермско-кайнозойское время, проявившейся в литофациальном облике осадочных толщ, характеризующихся преимущественно гумусовым рассеянным ОВ, содержащихся в породах, и их обильной углистостью, формировавшихся в бореальных зонах, отличающихся отсутствием литогенных и биогенных индикаторов теплого климата. В заключительной части доклада подчеркивалась необходимость «... рекомендовать при составлении перспективного плана развития энергетики и химической промышленности, связанных с нефтепоисковыми работами, на севере Сибири в первую очередь ориентироваться на развитие газовой промышленности» [5, с.220] (курсив мой. - Л.Н.).

Усмотрев в докладе «абсолютизацию» роли климатического фактора в накоплении нефтематеринского ОВ, Экспертная комиссия с выводами автора не согласилась.

После того как на севере Западной Сибири были открыты все известные в настоящее время гигантские газовые и газоконденсатные скопления и не было выявлено ни одного крупного скопления нефти, многие исследователи западно-сибирских недр прогнозировали открытие на севере Тюменской области крупных скоплений нефти, соизмеримых со среднеобскими. Подобные прогнозы нашли отражение в решении Всесоюзного совещания по проблеме поисков нефти в нижнемеловых и юрских отложениях на севере Тюменской области (Уренгой, 6-7 апреля 1972 г.).

В решении, принятом совещанием, обращается внимание на то, что «... полученные данные подтверждают высокие перспективы нефтегазоносности нижнемеловых и юрских отложений на севере Тюменской области и реальность оценки прогнозных запасов нефти и конденсата, которые составляют более 50\% от всех запасов 3 ападной Сибири» [20, с. 218], (курсив мой - Л.Н.). Для подтверждения этого прогноза в суровых субарктических условиях пробурено около десятка сверхглубоких (до 7 км) нефтепоисковых скважин, 
не оправдавших надежды авторов дорогостоящих проектов.

Шло время. По образному определению С.П. Максимова и В.П. Строганова [15, с. 5-19], север Западной Сибири оказался «главным полюсом газонакопления нашей планеты» [15, с. 14]. Промышленно-газоносными проявили себя только мезозойские отложения Енисей-Хатангского прогиба и Лено-Вилюйской впадины и кайнозойские осадочные толщи Камчатки. Преимущественно газоносными оказались кайнозойские отложения Анадырской и Хатырской впадин Чукотки, а также кайнозойские отложения Аляски и мезозойскокайнозойский осадочный комплекс Арктической Канады [5, рис.2]. Во всех названных регионах газоносность связывается с терригенным ОВ.

Исследуя геохимические и историко-геологические особенности образования нефти и битумов в пермских и мезозойских отложениях северовостока Сибирской платформы, И.Д.Полякова и О.Ф.Стасова [21] сочли обоснованной их генетическую связь (за исключением нефтепроявлений и битумов на севере Вилюйской синеклизы, образование которых связывается с пермскими угленосными толщами) с раннесреднепалеозойскими отложениями.

\section{Угленосные и субугленосные отложения - источник образования парафинистой нефти}

Основная масса парафинистой нефти образована постпалеозойскими угленосными и субугленосными отложениями. Ее скопления обнаружены практически на всех континентах. Это особенно наглядно отражено в публикации Г.Д.Гедберга [22], содержащей сведения по 500 анализам парафинистой нефти из 40 региональных стратиграфических последовательностей пяти континентов. Вместе с тем результаты лабораторного моделирования и опыт поисковоразведочных работ свидетельствуют о низком нефтегенерационном потенциале терригенного OB. Он в 10-12 раз ниже, нежели у материнских толщ с ОВ аквагенной природы [23].

Главная причина низкого нефтегенерационного потенциала терригенного ОВ - дефицит водорода и обогащение кислородом. У гумусового OB отношение $\mathrm{H} / \mathrm{C}$ обычно $<1,0$, а атомарное отношение $\mathrm{O} / \mathrm{C}$ - в пределах 0,2-0,3, тогда как у аквагенного ОВ этот показатель соответственно $>1,5$ и $<0,1$. При этом образование парафинистой нефти происходит только в жестких условиях катагенеза при $R$ o > 0,6\% [24-26]. По парафинистости нефти судят о качестве нефтематеринского OB и о генерационном потенциале вмещающих его отложений [27]. Некоторые газовые скопления севера Западной Сибири имеют нефтяные оторочки с нефтями, как правило, отличающимися высокой парафинистостью и отношением пристана к фитану - показателем «терригенистости» материнского ОВ - 2,0-6,1 [26, 28]. Насыщенная высокомолекулярными алканами нефть (содержание парафина иногда превышает 20\%) выявлена в Анадырской впадине. Генетически Д.И.Агапитов и соавторы [29] связывают чукотскую нефть с терригенным ОВ вмещающих отложений, а Е.И.Кудрявцева и соавторы [30] видят ее «корни» на глубине 7-10 км.

На Европейском Севере (Россия) высокопарафинистые нефти обнаружены в подстилающихся угленосными и субугленосными отложениями мезозойских коллекторах материковой части Тимано-Печорской нефтегазоносной провинции и на острове Колгуев [31].

\section{Палеозойский терригенно-карбонатный комплекс - реальный “донор" нефти в мезозойские коллекторы севера Сибири}

Судя по нефтенасыщенности мезозойских отложений Западной Сибири, существенную роль в образовании скоплений нефти этого региона играли инъекции жидких УВ, генетически связанных с палеозойскими нефтематеринскими толщами. Впервые на это обратили внимание М.И.Варенцов и Н.С.Кузнецов [32], выделяя в качестве генератора западно-сибирской нефти комплекс валанжинских, юрских и более древних пород северной, наиболее погруженной части осадочно-породного бассейна. Такая же оценка роли палеозойских осадочных пород и рифогенных образований в формировании промышленных скоплений нефти Западной Сибири дается во многих публикациях [33, 34].

О реальности существенных перетоков палеозойской нефти в мезозойские коллекторы свидетельствует оценка потенциальных возможностей палеозойского субстрата в Западной Сибири коллективом авторов монографии [35]. В заключительной части монографии обращается внимание, что «в пределах Западно-Сибирской плиты выделяется группа седиментационных бассейнов, выполненных доюрскими карбонатными, терригенными и эффузивно-осадочными породами... Общая площадь этих осадочных бассейнов превышает 1 млн 400 тыс. км², мощность их осадочного выполнения варьирует от первых сотен до 6-7 тыс. м, а объем осадочных пород превышает 2,5 млн км ${ }^{3}$. По площади и объему осадочного выполнения эти бассейны превышают такие нефтегазоносные провинции, как Волго-Уральская, Прикаспийская, Туранская, Тимано-Печорская и др.» $[35$, с. 645$]$.

Весомость нефтегенерационных возможностей рифейско-каледонского этажа Сибири обосновывается многими исследователями [36-39]. Л.Ш.Гиршгорн и соавторы [37] обращают внимание на «огромный» нефтегенерационный потенциал палеозойских карбонатных отложений этого региона. Последнее согласуется с нашим обоснованием [39] оптимизации условий образования УВ в щелочной среде карбонатных 
осадков уже в диагенетическую стадию катагенеза и с результатами исследований С.П. Левшуновой [40], установившей более высокий, нежели у терригенных, нефтегенерационный потенциал карбонатных пород.

В этой связи находит объяснение выявление в мезозойских коллекторах (на фоне преобладающей газоносности осадочного комплекса) относительно крупных нефтяных скоплений на севере Тюменской области вследствие перетоков нефти из подстилающих палеозойских терригенных и карбонатных материнских пород. В палеозойских отложениях северосибирских ОПБ промышленная нефть обнаружена в низовьях Енисея, в области сочленения Сибирской платформы и Западно-Сибирской плиты [41]. Высокий нефтегенерационный потенциал палеозойских терригенно-карбонатных отложений ЕнисейскоХатангского регионального прогиба обосновывается А.А.Салиховым и В.Б.Хмелевским [42].

Крупные скопления нефти в мезозойских коллекторах обнаружены на севере Аляски. Л.Б.Магун и Г.Е.Клейпул [43] рассматривают «большую» североаляскинскую нефть месторождения Прудхо-Бей (Prudhoe Вау) как «возрожденную» (по В.А.Успенскому) генерацию гипергенно-измененной палеозойской нефти. Это подтверждается ее большой, аномальной для высоких пластовых температур, плотностью и высокой сернистостью, не характерной для нефтей, генетически связанных с терригенными материнскими породами. Л.Б.Магун и Г.Е.Клейпул [43] видят в этом одну из важнейших улик генетической связи большей части североаляскинской нефти с палеозойскими карбонатными отложениями.

\section{О перспективах нефте- и газоносности арктического шельфа России}

Осадочный комплекс шельфа арктических морей России изучен фрагментарно. Спорадические исследования осадочных толщ с помощью бурения проводятся только на шельфе Баренцева, Печорского и Карского морей. О недрах шельфа моря Лаптевых, ВосточноСибирского, Чукотского и Берингова морей обычно судят по геологическому строению материкового прибрежья и островов. Крупное, и пока единственное, скопление тяжелой слабопарафинистой сернистой нефти (по этим параметрам она напоминает североаляскинскую нефть месторождения Прудхо-Бей [43]) выявлено на Приразломном месторождении в пределах печороморского шельфа [44]. Как и следовало ожидать, исходя из установленных закономерностей, нефть Приразломного месторождения обнаружена в карбонатных отложениях тепловодного каменноугольного-раннепермского моря. Тяжелая слабопарафинистая нефть, генетически связанная с палеозойскими карбонатными отложениями, обнаружена в триасовых терригенных коллекторах ряда месторождений на подводном продолжении вала Сорокина в Печорском море [45].

Собственно триасовыми терригенными отложениями порождена промышленная парафинистая нефть на Песчаноозерском нефтегазовом месторождении острова Колгуев [45]. Промышленная газоносность триасовых отложений на баренцевоморском, печороморском шельфе и шельфе Карского моря установлена на Мурманском, Северо-Кильдинском, Ленинградском и Русановском месторождениях.

В среднеюрских терригенных отложениях баренцевоморского шельфа выявлено уникальное скопление УВ газа на Штокмановском газоконденсатном месторождении. Значительные скопления газа в юрских коллекторах выявлены также на Лудловском, Ледовом, Северо-Кильдинском и Мурманском месторождениях [46].

Палеозойский осадочный комплекс в пределах шельфа арктических морей России представлен преимущественно карбонатными отложениями [47]. Доступными для исследования с помощью бурения могут быть главным образом верхнепалеозойские отложения, которые восточнее карского шельфа отличаются угленосностью позднекаменноугольных и пермских отложений[37, 48]. Мезозойские отложения арктического шельфа сложены преимущественно терригенными, в различной степени угленосными, формациями $[12,18,49,50]$.

Литолого-фациальные особенности палеозойского осадочного комплекса, за исключением преимущественно угленосных отложений позднего карбона и перми к востоку от печорского шельфа, свидетельствуют о благоприятных (теплых) климатических условиях для биогенерации нефтема-теринского OB.

Терригенный, в различной степени угленосный, мезозойско-кайнозойский осадочный комплекс, так же как и преимущественно угленосные отложения позднего карбона и перми, может быть источником преимущественно газовых и газоконденсатных скоплений и незначительных скоплений парафинистой нефти. Палеозойские отложения шельфа арктических морей безусловно будут родиной и «большой» нефти. Но ее поиски, разведка, извлечение и транспортировка в арктических условиях практически круглогодичной тяжелой ледовой обстановки не будут легкими. $\mathrm{C}$ еще большими трудностями будет сопряжена эксплуатация скоплений парафинистой нефти.

Из известных нам публикаций, освещающих особенности геологического строения шельфа арктических морей России в связи с оценкой перспектив его нефтегазоносности, наиболее конкретной информативностью о нефтегазогенерационном потенциале осадочно-породных бассейнов выделяется статья Ф.К.Салманова и соавторов [51]. Эти авторы обращают внимание, что при определении углеводородного потенциала 
ОПБ они опирались на четыре методики. Однако, судя по содержанию статьи, основой для определения потенциальных возможностей осадочных толщ арктического шельфа России явилась методика определения концентраций УВ ресурсов осадочно-породных бассейнов в зависимости от объемной скорости их заполнения осадочным материалом, разработанная В.В.Потеряевой и соавторами [52].

В отличие от общепринятого способа отражения скорости накопления осадочных толщ путем определения темпа их нарастания в линейных единицах или же в единицах веса на единицу площади [5], В.В.Потеряева и соавторы [58] сочли целесообразным определять объемную скорость заполнения палеоседиментационного бассейна осадками, выражающуюся в соотношении объема породных комплексов к продолжительности их формирования. Но такой подход к оценке нефтегенерационного потенциала ОПБ, без учета удельной скорости нарастания осадков, может поставить в равные условия бассейны, содержащие большую часть осадочного выполнения в глубоких и емких впадинах (прогибах) - основных генераторах углеводородов, с бассейнами, лишенными таких мощных резервуаров-реакторов, но обладающих равновеликим объемом осадочного выполнения, накопившегося в сходном временном диапазоне и отличающегося равномерным распределением осадочных толщ на большей части палеобассейна [53].

Примером того являются нефтегазоносные бассейны Западной Сибири и Персидского залива. Согласно расчетам И.И.Нестерова, В.В.Потеряевой и Ф.К.Салманова [52, табл.12], эти ОПБ, содержащие примерно равновеликие объемы осадочного выполнения (соответственно 6000 и 7041 тыс.км³ ), заполнялись осадками с одинаковой объемной скоростью - 30 тыс.км ${ }^{3} /$ млн лет. Если же обратить внимание на степень равномерности распределения в них осадочных образований, то становится очевидным, что сравнительная оценка нефтегазогенерационного потенциала этих палеобассейнов, основанная только на средней скорости заполнения осадками, по своей сути не корректна.

В отличие от Западной Сибири, где средние толщины мезозойско-кайнозойского осадочного выполнения впадины (2,6 км) на большей ее части близки к максимальным (3,6 км), в Месопотамской впадине Персидского залива основной объем осадков (более $5000 \mathrm{kм}^{3}$ ) сосредоточен в Предтавро-Загрос-Оманском прогибе, имеющем длину 2000 км, ширину 500 км и толщину осадочного выполнения 15 км и более [54]. Средневзвешенный удельный темп накопления осадков в Западной Сибири (64 т/км²/год) в 6,5 раза ниже, нежели в Месопотамской впадине (420 т/км²/год). Все это, а также расположение ОПБ Персидского залива во время осадконакопления в тропических палеоширотах [7], стало первопричиной обнару- жения в пределах Месопотамской впадины более 65 млрд т нефти и 15 трлн м 3 газа, а потенциально извлекаемые запасы нефти здесь определяются более 100 млрд т [54]. Скважины эксплуатируются преимущественно за счет энергии пласта.

Если обратиться к результатам определения потенциальных ресурсов УВ в пределах шельфа арктических морей России, полученным Ф.К.Салмановым с соавторами [52], то они характеризуют недра арктического шельфа России более насыщенными УВ (152-200,5 млрд т), чем УВ ОПБ Персидского залива. Разумеется, такая оценка УВ потенциала шельфа полярных окраинных морей может только дезориентировать планирование пополнения нефтегазовых ресурсов.

Нет сомнения, что скорость прироста объема осадочного выполнения ОПБ в сочетании с длительностью седиментации - важнейший фактор нефтегенерационного потенциала ОПБ. Но его реализация находится в прямой зависимости от темпа нарастания осадочных толщ, контролирующего как накопление потенциального нефтематеринского органического вещества, так и динамику энергетического обеспечения литогенеза, и как следствие масштабы образования углеводородов [5].

В реальных геологических условиях оценка перспектив нефтегазоносности осадочно-породных бассейнов должна опираться прежде всего на скорость удельного прироста массы осадков, характеризующую масштабы фоссилизации органического вещества и энергетическую обеспеченность литогенеза в ходе генерации углеводородов. Объемная же скорость накопления осадков в наиболее погруженных частях палеоседиментационных бассейнов - генераторах углеводородов в сочетании со скоростью удельного прироста массы осадков является носителем информации о потенциальных ресурсах углеводородов.

\section{Заключение}

Рассмотрение одной из фундаментальных проблем генезиса нефти и газа, касающихся зависимости качественной и количественной сторон образования углеводородов от палеоклиматических (биономических) условий генерации органического вещества земной биосферой как в глобальных масштабах, так и в региональных, присущих отдельным палеоседиментационным бассейнам, еще раз убеждает в незыблемости главного положения теории нефтеобразования о генетической связи углеводородов в промышленных скоплениях с продукцией биосинтеза органического вещества. Прямая зависимость продуктивности биомассы от среднегодовой температуры в фотическом слое водоемов породила локализацию $80 \%$ фанерозойской нефти в палеоседиментационных бассейнах, находившихся в период накопления нефтематеринских толщ в приэкваториальном палеоширотном диапазоне $0-30^{\circ}$. 
Высокий газогенерационный потенциал терригенного органического вещества - главного источника органической массы в угленосных и субугленосных отложениях - и перемещение в посткарбоновое время накопления основной массы углематеринского ОВ в бореальные зоны породили пространственное размежевание областей преимущественно нефте- и газообразования. Посткаменноугольные отложения палеобореальных зон оказались генераторами большей части глобальных скоплений углеводородных газов [4]. В жестких условиях катагенеза угленосные и субугленосные отложения могут быть источниками парафинистой нефти. Их генерационный потенциал в 10-12 раз ниже, нежели у аквагенного органического вещества, что сказывается на величинах нефтяных скоплений.

Важнейшим результатом исследований, начатых нами в середине 50-х гг. XX в., является подтверждение поисковыми работами преимущественной газоносности посткарбоновых отложений севера Сибири.

Выявленные закономерности проявляются и при проведении нефтегазопоисковых работ на шельфе арктических морей России. Преимущественно карбонатные отложения палеозойских тепловодных морей в зонах, доступных для их разбуривания, при благоприятном сочетании всех факторов образования и аккумуляции нефти, будут промышленно нефтеносными. Об этом свидетельствуют нефтепоисковые работы на шельфе Печорского моря, увенчавшиеся открытием крупного нефтяного скопления в карбонатных породах позднекарбонового-раннепермского возраста на Приразломном месторождении.

Поисковые работы в мезозойском бореальном терригенном осадочном комплексе на шельфе трех западных арктических морей России увенчались открытием ряда газовых скоплений и одного небольшого скопления парафинистой нефти на острове Колгуев, генетически связанной с вмещающими отложениями. Генераторами крупных, в том числе уникальных, подобных Штокмановскому, скоплений углеводородных газов могут быть не только мезозойские и кайнозойские отложения, но и угленосные и субугленосные толщи позднекарбонового и пермского возраста в ОПБ моря Лаптевых, Восточно-Сибирского, Чукотского и Берингова морей. В позднекарбоново-кайнозойских отложениях шельфа восточных окраин арктических морей, в различной степени обогащенных терригенным органическим веществом, возможны незначительные скопления парафинистой нефти.

При оценке прогнозных запасов углеводородов недр арктического шельфа, помимо объемной скорости заполнения осадками палеоседиментационных бассейнов, следует учитывать и скорость удельного прироста массы осадков, во многом определяющую масштабы фоссилизации органического вещества, энергетический потенциал литогенеза и, как следствие, масштабы генерации углеводородов.

\section{Библиографический список}

1. Назаркин Л.А. Роль палеоклимата в прогнозах нефтегазоносности крупных регионов. Саратов, 1955. 143 с.

2. Nazarkin L.A. Climate and oil genesis // Intern. Geol. Review. 1961. Vol. 2. P. 141-146.

3. Назаркин Л.А. Палеоклиматически обусловленное размещение нефтяных месторождений - неоспоримое доказательство биогенного происхождения нефти // Генезис нефти и газа. М., 1967. С. 87-93.

4. Назаркин Л.А. Зависимость газоносности пермских, мезозойских и кайнозойских отложений от палеоклиматических условий их накопления // Сов. геология. 1987. № 2. C. $76-84$.

5. Назаркин Л.А. О палеоклиматическом и динамикоседиментационном контроле нефтегазообразования. Саратов, 1994. $224 \mathrm{c}$.

6. Рябченко B.A. Сезонная изменчивость первичной продукции в Мировом океане (по результатам расчетов) // Докл. АН СССР. 1990. Т. 313, № 2. С. 441-445.

7. Irving E., North E.K., Couillard R. Oil, climate and tectonics // Can. J. Earth. Sci. 1974. Vol. 11, № 1. P. 1-17.

8. Жемчужников Ю.А. Предпосылки углеобразования // Зап. Ленингр. горн. ин-та. 1958. Т. 33, вып. 2. С. 6-19.

9. Брайден С.Дж., Ирвинг Е. Спектры палеоширот осадочных палеоклиматических индикаторов // Проблемы планетарной палеоклиматологии. М., 1968. С. 104-129.

10. Синицын В.М. Введение в палеоклиматологию. Л., 1980. $248 \mathrm{c}$.

11. Багринцева К.А., Васильев В.Т., Ермаков В.И. Роль угленосных толщ в процессах генерации природного газа // Геол. нефти и газа. 1968. № 6. С. 7-11.

12. Ермаков В.И., Скоробогатов В.А. Образование углеводородных газов в угленосных и субугленосных формациях. M., 1984. 205 c.

13. Голищын М.В., Голичын А.М., Андросов Б.А.и др. Угли Западной Сибири // Изв. вузов. Геология и разведка. 1992. № 2. С. 75-83.

14. Условия раздельного формирования зон нефте- и газонакопления в земной коре // Тр. ЗапСибНИГНИ. Тюмень, 1978. Вып. 137. 152 с.

15. Условия раздельного формирования зон нефте- и газонакопления в нефтегазоносных бассейнах СССР и зарубежных стран // Там же. Тюмень, 1978. Вып. 138. $172 \mathrm{c}$.

16. Генезис углеводородных газов и формирование месторождений. М., 1977. 291 с.

17. Проблемы газоносности СССР // Сб. науч. тр. ВНИИГАЗ). М., 1990. $356 \mathrm{c.}$

18. Жабрев И.П., Ермаков В.И., Орел В.Е. и др. Генезис газа и прогноз газоносности // Геол. нефти и газа. 1974. № 9. C. 1-9.

19. Строганов Л. В. Некоторые особенности геологического строения и генерации газа меловых отложений Ямала // Там же. 1988. № 5. С. 16-19.

20. Проблемы поисков нефти в нижнемеловых и юрских отложениях на севере Тюменской области (материалы Уренгойского совещания) // Тр. ЗапСибНИГНИ. Тюмень, 1973. Вып. 70. 221 c. 
21. Полякова И.Д., Стасова О.Ф. Геохимия нафтидов северо-востока Сибирской платформы в связи с условиями их формирования и разрушения // Геохимические и гидрогеологические предпосылки поисков нефти и газа в Сибири. Новосибирск, 1983. С.70-82.

22. Hedberg H.D. Significance of high wax oils in the generation of petroleum // Bull. Amer. Assoc. Petrol. Geol. 1968. Vol. 52. № 5. Р. 736-750.

23. Гончаров И.В. Геохимия нефтей Западной Сибири. М., 1987. $181 \mathrm{c}$.

24. Snowdon L.R., Powell T.O. Immature oil and condensatemodification of hydrocarbon generation model for terrestrial organic matter // Bull., Amer. Assoc. Petrol. Geol. 1982. Vol. 66. № 6. P. 775-788.

25. Evans R.J., Flebeck G.T. High temperature simulation of petroleum formation-Ill. Effects of organic strating material structure of hydeocarbon formation // Organic Geohemistry. 1983. Vol. 4. № 3/4. P. 153-160.

26. Петров А.Л. Углеводороды нефти. М., 1984. 264 с.

27. Sofer Z. Stable carbon isotope compositions of crude oils: application to source depositional environment and petroleum alteration // Bull., Amer. Assoc. Petrol. Geol. 1984. Vol. 68. № 1. P. 775-788.

28. Гончаров И.В., Крашин Д.И., Шпильман К.А. О природе нефтей и газа Тюменской области // Геол. нефти и газа. 1983. № 3. С. 34-38.

29. Агапитов Д.И., Косыгин Ю.А., Мотовилов Ю.В. и др. Новые данные о перспективах нефтегазоносности СевероВостока СССР // Там же. 1983. № 7. С. 1-5.

30. Кудрявцева Е.И., Крылова Т.А., Дертев А.К. и др. Изотопный состав углерода нефтей Чукотки // Докл. АН СССР. 1990. Т. 310, № 6. С. 1450-1453.

31. Ботнева Т.А., Шулова И.С. Генерация и аккумуляция углеводородов в Тимано-Печорской провинции // Сов. геология. 1991. № 9. С. 13-19.

32. Варенцов М.И., Кузнецов И.С. Особенности размещения месторождений нефти и газа на территории Западной Сибири // Докл. АН СССР. 1974. Т. 218, № 4. С. 905-908.

33. Сорохтин О.Г., Баланюк Н.Е. О связи нефтегазоносности с зонами поддвига литосферных плит// Океанология. 1981. Т. 22, вып. 2. С. 136-245.

34. Шаблинская Н.В., Прасолов Э.М. Промежуточный комплекс севера Западной Сибири - возможный источник углеводородов // Докл. АН СССР. 1988. Т. 300, № 2. C. $422-426$.

35. Геология нефти и газа Западной Сибири / А.Э. Конторович, И.И. Нестеров, Ф.К. Салманов и др. / М., 1975. 680 с.

36. Гиригорн Л.Ш., Кабальљк В.Г., Соседков В.С. Нижнесреднепалеозойский осадочный бассейн севера Западной Сибири // Сов. геология. 1987. № 11. С. 65-75.

37. Максимов С.П., Самолетов М.В., Немченко Н.Н. и др. Палеозойский карбонатный комплекс - перспективный объект залежей УВ на Ямале // Геол. нефти и газа. 1987. № 10. C.30-36.

38. Запивалов Н.П., Каштанов В.А., Кирда Н.П., Степанов С.А. Прогнозирование крупных зон нефтегазонакоп- ления в рифейско-фанерозойских комплексах Западной Сибири // Теоретические и региональные проблемы геологии нефти и газа. Новосибирск, 1991. С. 143-452.

39. Назаркин Л.А. О диагностике нефтематеринских пород // Уч. записки Сарат. ун-та. Вып. Геологический. 1959. T. 65. C.138-143.

40. Левщунова С.П. О необходимости внешних источников водорода для образования углеводородов в осадочных породах // Геол. нефти и газа. 1995. № 12. С.28-30.

41. Соколов Б.А., Усманов И.М. Геологическое строение и перспективы нефтегазоносности области сочленения Сибирской платформы и Западно-Сибирской плиты // Изв. вузов. Геология и разведка. 1982. № 2. C. 35-40.

42. Салихов А.А., Хмелевский В.В. Строение доюрского комплекса юго-западной части Енисейско-Хатангского регионального прогиба // Геол. и геофизика. 1991. № 11. C. 85-92.

43. Magoon L.B., Claypool G.E. Two oil types on the North Slope of Alaska. Implications for nature exploration // Rw. Inst. fr. Petrole. 1980, Vol. 35, № 2. P. 245-256.

44. Никитин Б.А., Хведчук И.И. Нефтяное месторождение Приразломное на арктическом шельфе России // Геол. нефти и газа. 1997. № 2. С. 26-29.

45. Захаров Е.В., Кулибакина И.Б. Перспективы нефтегазоносности триасового комплекса на шельфе Баренцева и Печорского морей // Там же. 1996. № 10. С. 21-25.

46. Захаров Е.В., Юнов А.Ю. Направления поисков залежей УВ в юрских отложениях на российском шельфе Баренцева моря // Там же. 1994. № 2. С. 13-15.

47. Тектоника и перспективы нефтегазоносности окраинных и внутренних морей. Группа впадин арктических морей / Р.М.Деменицкая, Л.Э.Левина // Тектоника и нефтегазоносность окраинных и внутренних морей СССР. Л., 1970. Вып. 20. С. 252-272.

48. Рябухин Г.Е., Зинин В.А. Перспективы нефтегазоносности верхнепалеозойских отложений шельфа арктических морей // Геол. нефти и газа. 1992. № 7. С. 2-4.

49. Рябухин Г.Е., Зинин В.А. Перспективы нефтегазоносности триасовых формаций шельфа арктических морей России // Там же. № 12. С. 2-5.

50. Рябухин T.E., Зинин В.А. Перспективы нефтегазоносности юрских формаций шельфа арктических морей СССР // Там же. 1991. № 12. С. 2-5.

51. Салманов Ф.К.,, Грамберг И.С., Клещев К.А. и др. Нефть и газ Арктики - энергетика мира будущего // Там же. 1994. № 3. С. 4-10.

52. Нестеров И.И., Потеряева В.В., Салманов Ф.К. Закономерности распределения крупных месторождений нефти и газа в земной коре. М., 1975. 278 с.

53. Назаркин Л.А. Скорость седиментации и нефтегазогенерационный потенциал осадочно-породных бассейнов // Изв. АН СССР. Сер. Геология. 1984. № 1. 117-122.

54. Проблемы тектоники и нефтегазоносности краевых прогибов / М.И. Варенцов, С.М. Дорошко, И.К. Королюк, и др. М., 1973. 232 с. 